\title{
EFFECT OF CRUSTING OPERATIONS ON THE PHYSICAL PROPERTIES OF LEATHER
}

\author{
Kallen Mulilo NALYANYA ${ }^{1}$, Ronald K. ROP ${ }^{1}$, Arthur ONYUKA ${ }^{2}$, Zephania BIRECH ${ }^{3}$, Alvin SASIA ${ }^{2}$ \\ ${ }^{1}$ Department of Physics, Faculty of Science, Egerton University, Nakuru, Kenya, kallenmulilo@ymail.com \\ ${ }^{2}$ Kenya Industrial Research and Development Institute, Nairobi, Kenya \\ ${ }^{3}$ Department of Physics, School of Biological and Physical Sciences, University of Nairobi, Kenya
}

Received: 19.07.2018

Accepted: 13.10 .2018

https://doi.org/10.24264/Ifj.18.4.4

\section{EFFECT OF CRUSTING OPERATIONS ON THE MECHANICAL PROPERTIES OF LEATHER}

ABSTRACT. Physical properties of leather form vital quality parameters that determine the performance characteristics in their areas of applications. However, the transformational processing of hide to leather involves a series of both chemical and physical/mechanical changes that affect these mechanical properties. Many researches have been published regarding the effect of processing on the mechanical properties of leather. However, the effect of entire crusting operations (post tanning) on the mechanical properties is not documented. This study reports the findings of the effect of crusting operations (retanning, dyeing and fatliquoring) on the mechanical properties of the final leather. Results have shown that retanning process improves tear and tensile strengths, distensions at crack and burst, and shrinkage temperature. An improvement in the organoleptic properties such as fullness was recorded in retanned crust leather. However, the uniformity coefficient and percentage elongation significantly decreased after retanning. Dyeing raises the elongation at break, distensions at crack and burst, shrinkage temperature and uniformity coefficient whereas both tensile and tear strengths decreased after dyeing. Similarly, fatliquored samples recorded higher elongation at break values, and distension values. Conversely, tensile and tear strengths, shrinkage temperature and uniformity coefficient decreased as a result of fatliquoring process. All the samples tested at tanning, retanning, dyeing and fatliquoring processes indicated no damage at 50,000 flexes. The study discussed these effects using transmission of fracture and damage mechanics in leather, structural implication of the resulting leather and existing models of materials.

KEYWORDS: physical properties, crusting operations, leather anisotropy and uniformity, fracture and damage mechanics, micromechanical deformation, stress concentration

\section{EFECTUL OPERATIUNILOR DE FINISARE UMEDĂ ASUPRA PROPRIETĂTILOR MECANICE ALE PIELII}

REZUMAT. Proprietățile fizice ale pielii constituie parametri de calitate importanți care determină caracteristicile de performanță ale pielii în domeniile în care vor fi utilizate. Cu toate acestea, transformarea pieii crude în piele finită implică o serie de modificări chimice şi fizicomecanice care afectează proprietățile mecanice ale pielii. Au fost publicate multe cercetări privind efectul prelucrării asupra proprietăților mecanice ale pielii. Cu toate acestea, efectul ansamblului de operațiuni de finisare umedă (post-tăbăcire) asupra rezistenței mecanice nu este documentat. Acest studiu prezintă constatările privind efectul operațiunilor de finisare umedă (retăbăcire, vopsire şi ungere) asupra proprietăților mecanice ale pieii finite. Rezultatele au arătat că procesul de retăbăcire îmbunătățește rezistența la rupere şi la sfâșiere, alungirea la crăpare şi rupere şi temperatura de contracție. S-a înregistrat o îmbunătăţire a proprietăților organoleptice, cum ar fi plinătatea, la pielea retăbăcită și finisată umed. Cu toate acestea, coeficientul de uniformitate și alungirea procentuală au scăzut semnificativ după retăbăcire. Vopsirea crește alungirea la rupere, alungirea la crăpare şi rupere, temperatura de contracție şi coeficientul de uniformitate, în timp ce rezistența la rupere şi la sfâșiere scad după vopsire. În mod similar, eșantioanele unse au înregistrat valori mai mari ale alungirii la rupere şi ale alungirii la crăpare şi rupere. Dimpotrivă, rezistența la rupere şi la sfâșiere, temperatura de contracție şi coeficientul de uniformitate au scăzut ca rezultat al procesului de ungere. Nicio probă testată după tăbăcire, retăbăcire, vopsire şi ungere nu a prezentat deteriorare la 50.000 de flexiuni. Studiul a prezentat aceste efecte prin propagarea fracturii şi deteriorările mecanice ale pielii, proprietățile structurale ale pielii rezultate şi modelele de materiale existente.

CUVINTE CHEIE: proprietăți fizice, operațiuni de finisare umedă, anizotropia şi uniformitatea pielii, fracturi şi deteriorări mecanice, deformare micromecanică, concentrație de stres

\section{L'EFFET DES OPÉRATIONS DE FINITION HUMIDE SUR LES PROPRIÉTÉS MÉCANIQUES DU CUIR}

RÉSUMÉ. Les propriétés physiques du cuir forment des paramètres de qualité vitaux qui déterminent les caractéristiques de performance dans leurs domaines d'application. Cependant, le traitement de la peau en cuir implique une série de modifications tant chimiques que physiques/mécaniques qui affectent les propriétés mécaniques du cuir. De nombreuses recherches ont été publiées concernant l'effet du traitement sur les propriétés mécaniques du cuir. Cependant, l'effet de l'ensemble des opérations de finition humide (après tannage) sur la résistance mécanique n'est pas documenté. Cette étude présente les résultats de l'effet des opérations de finition humide (retannage, teinture et nourriture) sur les propriétés mécaniques du cuir final. Les résultats ont montré que le processus de retannage améliore les résistances à la déchirure et à la traction, l'extension à la gerçure et à l'éclatement, la température de rétraction. Une amélioration des propriétés organoleptiques telles que la plénitude a été enregistrée dans le cuir retanné et fini humide. Cependant, le coefficient d'uniformité et le pourcentage d'allongement ont significativement diminué après retannage. La teinture augmente l'allongement à la rupture, l'extension à la gerçure et à l'éclatement, la température de rétraction et le coefficient d'uniformité, tandis que les résistances à la traction et à la déchirure diminuent après la teinture. De manière similaire, les échantillons nourris ont enregistré des valeurs plus élevées d'allongement à la rupture et d'extension. Inversement, les résistances à la traction et à la déchirure, la température de rétraction et le coefficient d'uniformité ont diminué à la suite du processus de nourriture. Aucun des échantillons testés lors des processus de tannage, de retannage, de teinture et de nourriture $n$ 'indiquent aucun dommage après 50000 flexions. L'étude a examiné ces effets en utilisant la transmission de la rupture et les dommages mécaniques dans le cuir, les propriétés structurelles du cuir résultant et les modèles de matériaux existants.

MOTS CLÉS : propriétés physiques, opérations de finition humide, anisotropie et uniformité du cuir, rupture et dommages mécaniques, déformation micromécanique, concentration de stress

* Correspondence to: Kallen Mulilo NALYANYA, Department of Physics, Faculty of Science, Egerton University, Nakuru, Kenya, P.O. Box 536, Egerton-20115, Phone: +254712627620, Fax: 25451 22178257, email: kallenmulilo@ymail.com 


\section{INTRODUCTION}

Leather is an important intermediate industrial product in the down-stream sectors of the consumer products industry [1]. The conventional applications include footwear, clothing, upholstery, and furniture $[2,3]$. Physical properties in this case play an important role of determining the specific field of applications since they determine the required performance characteristics $[1,4$, 5]. However, the transformational journey of bovine hide to leather involves a sequence of chemical and mechanical operations that greatly alter these properties [6]. The operations can be categorized into beam house (pretanning), tanning, post-tanning (crusting or wet-finishing) and dry-finishing operations [7]. Beam house operations prepares the hide for tanning by removing the hairs, flesh and fats that accelerate the degradation and opening up the pelt structure for tanning agents [8]. Among the leather making operations, tanning is the most outstanding operations that entirely transforms hides' putrescible proteins into physically and chemically stable collagen, known as leather [9]. Crusting operations involve retanning, dyeing and fatliquoring processes $[4,7]$.

A number of studies have investigated the effect of pretanning and tanning operations on the physical properties of leather [912]. Publications on the effect of retanning, fatliquoring and dry-finishing operations on the chemical and organoleptic properties of leathers are available [13-18]. Theoretically, retanning process imparts fullness into the leather. This involves the structural crosslinking within and among the collagens in the leather which consequently increases the mechanical stability [9]. Dyeing process gives the leather the base of the desired color. The dyes components interact with collagens in leather chemically and physically by electrostatic attraction. Therefore the interaction is expected to modify the structural and hence the mechanical integrity of the final leather. By the time of tanning, the pelt does not contain sufficient lubricants to prevent it from drying into a hard/stiff material [19]. For this reason, after tanning, proper lubrication is needful [20]. Lubrication is done through the incorporation of oils and fats into leather matrix in finely dispersed form in a water medium (emulsion) in the process referred to as fatliquoring. The oils and fats safeguard the leather against cracking or sticking together of its collagen fibres and becoming hard and stiff during drying [21]. This step results to hydrophobic leather [22]. Although fatliquoring is known to impart softness and a certain degree of water repellency, little is known about its effect on the structural and physical properties of leather. Since there are many polar functional groups in collagen such as $-\mathrm{OH},-\mathrm{COOH},-\mathrm{NH}_{2}$ and $-\mathrm{CONH}-$, then the processes of crusting operations that involve hydrophilic chemical compounds will be absorbed and affect structural bonds of the leather matrix [22]. Any effect on the structural or molecular bond impacts the structural and hence the physical properties [23]. Hence in this study, the effect of retanning, dyeing and fatliquoring processes on the physical properties have been investigated using tensile tester (Instron 1011). The physical properties investigated includes tensile strength, tear strength, elongation at break, flexing endurance, ball burst distension, shrinkage temperature and uniformity coefficient.

\section{EXPERIMENTAL}

\section{Materials}

Fresh cowhide, procured from the slaughterhouse, was processed to chrome tanning stage using conventional procedure as described in [12]. The wet blue leather was fixed using formic acid and cut into two identical pieces along the backline as shown in Figure 1. 


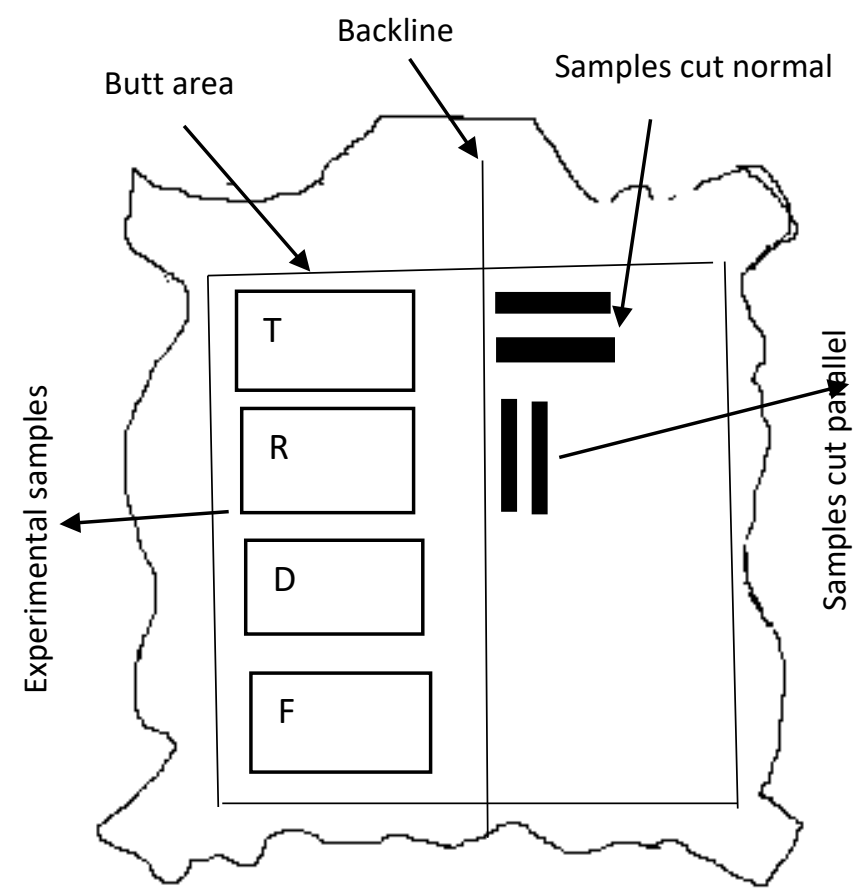

Figure 1. Representation of sample preparation and sample location

One quarter of one piece was cut out within the butt area and coded tanned sample $(T)$. The remaining three quarters proceeded to retanning stage using chromium sulphate in a drum. Before this stage, the wet blue was wetted in water, basified using sodium bicarbonate and then neutralized using ammonium bicarbonate. $1 \%$ of antimould and $2 \%$ of the sodium formate were also added during neutralization stage to prevent fungal growth and as a complexing agent to further improve chrome exhaustion after chrome tanning, respectively. Retannage was carried out using $150 \%$ water at $45^{\circ} \mathrm{C}$ and $6 \%$ retanning agent (chromium sulphateCromogenia Retanal BD Polvo) in a drum running moderately slow for 45 minutes. After penetration check, $1.5 \%$ formic was added to fix the crust. The crust was then drained, washed and toggled overnight prior to dyeing. A third of the crust was cut out within the butt area as retanned sample (R). To prepare the crust for dyeing, the remaining piece was basified using ammonium bicarbonate to adjust the $\mathrm{pH}$ to 6.5. Dyeing involved $100 \%$ water at $50^{\circ} \mathrm{C}$ and $2 \%$ of acidic HLC Novolene HC black dye, added through the axle as the drum runs. The crust was then fixed using formic acid before it was drained, washed and toggled overnight. Half of the crust was cut out within the butt area as dyed sample (D). The remaining crust was fatliquored using sulphited vegetable cromogenia Fosfol 51 oils. Water $\left(100 \%\right.$ at $\left.50^{\circ} \mathrm{C}\right)$ and $2 \%$ fat liquor was run in a drum for 45 minutes. After fixing, the fatliquored crust was drained, washed in $200 \%$ water, and toggled overnight. The crust was cut out and sample labeled as fatliquored (F).

\section{Sampling, Sampling Location and Sample Conditioning}

The specimens for mechanical tests were kept in a standard atmosphere of temperature $25 \pm 2^{\circ} \mathrm{C}$ and relative humidity of $65 \% \pm 2 \%$ for at least 48 hours according to ISO 2419: 2012. Sampling was done in accordance with the standard ISO 2418 (2005). In this procedure, the samples were cut within the "official sampling position (OSP)" within which, the variation in strength properties and anisotropy are gradual and minimal [1]. Cutting samples from the same hide also helped to minimize the variations of strength properties that arise due to differences in animal age, sex and breed [16]. For tensile strength, tear strength, percentage elongation and flexing endurance, eight (8) samples were cut; 4 sampled parallel while 4 sampled perpendicular to the backline. 


\section{Methods}

\section{Determination of Tensile Strength and Elongation at Break}

Tensile strength (also known as ultimate tensile strength) is the capacity of a material or structure to withstand loads tending to elongate it. Tensile strength determines the maximum tensile stress/tension that the leather can sustain without fracture [24]. Quantitatively, this can be expressed as the force required to rupture a material specimen of unit cross sectional area. In leather, this strength is thus the combined breaking strength of all the fibers which are taking part to fight against the applied load. For most leather end uses or applications, this strength must be adequate; the acceptable minimum tensile strength for chrome tanned is $20 \mathrm{Nmm}^{-2}$ (MPa) $[24,25]$.

Elongation refers to the ability of a material to lengthen/stretch when stress is applied to it and represents the maximum extent the material can stretch without breaking. In leather, this is an important quality parameter to be considered, especially when choosing garment leathers, because a low elongation value results in easy tear while a high elongation value causes leather goods to become deformed very quickly or even lose usability [4]. Good quality leathers should have a percentage elongation of at least 40\% [24-26].

For tensile strength and elongation, eight dumbbell-shaped (dog-bone shaped) test pieces (four from each principal direction) were cut from the crusts using special steel press knife in template according to ISO 3376: 2002 as described in [8]. The thickness of each specimen and mean thickness was measured in accordance to ISO 2589. These tests were carried out using tensile tester (Instron machine 1011) according to ISO 3376:2012 at a cross-head speed of 100 $\mathrm{mm} / \mathrm{min}$ at room temperature.

\section{Determination of Baumann Tear Strength/Slit Tear Resistance}

Tear strength (also known as tear resistance) is a measure of how well a material can withstand the effects of tearing. It specifically measures a material's resistance to the growth of any cuts when under tension, measured in
$\mathrm{N} / \mathrm{mm}$ [9]. In the leather fracture behavior, deformation and crack growth, this strength measures the resistance to the formation of a tear (tear initiation) and its corresponding expansion or growth (tear propagation within the structure). The least recommended tear strength for chrome-tanned shoe upper side leathers is $40 \mathrm{~N} / \mathrm{mm}$ [24-26]. In this test, the specimens were cut and tested in accordance to ISO 3377:2002.

\section{Measurement of Shrinkage Temperature}

Shrinkage temperature gives the temperature at which the leather starts to shrink in water or over a heating media [15]. This property is used to characterize the thermal stability of leather. It provides information about the degree of tanning, because the better the crosslinking reactions between the collagen fibres and the tannins, the higher the shrinkage temperature [27]. Good quality leather should have a minimum shrinkage temperature of $75^{\circ} \mathrm{C}$ [24]. In this study, the shrinkage temperature was measured using SATRA STD 114 test apparatus according to the official method (ISO 3380:2002) at a heating rate of $2^{\circ} \mathrm{C} / \mathrm{min}$.

\section{Measurement of Distension of Grain by the Ball Burst Test}

This is a property for testing quality of leathers intended to indicate the grain resistance to cracking during top lasting of the shoe uppers. The threshold recommended values for grain crack and grain burst for upper leathers is $6.5 \mathrm{~mm}$ and $7.0 \mathrm{~mm}$, respectively [26]. In this study, the ball burst test was measured using a Lastometer according to the official method (ISO 3379:1976).

\section{Flexing Endurance}

Bally flex or flexing endurance is an indication of the finishing resistance to crack and crease when repeatedly flexed, emulating the flexing of the actual use of the shoe. It's a very good indication of the ability of leather grain to withstand lasting operation during shoe making without cracks. Flexing endurance of the prepared leather crust was measured using SATRA STM 701 Bally flexometer according to the official method (ISO 5402:2002). The leather 
samples were subjected to pre-determined $100,500,1,000,5,000,10,000,20,000,50,000$ flexes/cycles and it was observed periodically for any signs of crack on the grain surface of the leather. Results were defined by observing tendency of cracking with the help of an illuminated lens (10 $\mathrm{x}$ magnifications).

\section{Statistical Analysis of Data}

Results were evaluated statistically by using One-Way ANOVA, descriptive statistical and represented as mean for four independent measurements. Comparison of means was analyzed and differences were considered as significant when $p<0.05$. Every value reported here is an average of four samples.

\section{RESULTS AND DISCUSSION}

The mean values of tensile strength, tear strength, percentage elongation and distension at crack and burst are reported in Table 1 .

Table 1: Physical properties of tanned, retanned, dyed and fatliquored leather

\begin{tabular}{|c|c|c|c|c|c|}
\hline Physical Properties & Direction & Tanned & Retanned & Dyed & Fatliquored \\
\hline \multirow{2}{*}{$\begin{array}{l}\text { Tensile Strength } \\
\qquad\left(\mathrm{N} / \mathrm{mm}^{2}\right)\end{array}$} & Normal & $20.05 \pm 0.21$ & $22.34 \pm 2.01$ & $19.7 \pm 1.79$ & $18.16+1.80$ \\
\hline & Parallel & $21.28 \pm 1.03$ & $24.15 \pm 2.08$ & $22.28 \pm 2.40$ & $19.04+1.67$ \\
\hline \multirow[t]{2}{*}{ Tear Strength (N/mm) } & Normal & $88.20 \pm 5.73$ & $106.14 \pm 7.31$ & $75.04 \pm 19.49$ & $86.87 \pm 9.69$ \\
\hline & Parallel & $74.60 \pm 3.08$ & $98.18 \pm 5.39$ & $70.10 \pm 13.88$ & $84.51 \pm 13.87$ \\
\hline \multirow[t]{2}{*}{ Elongation (\%) } & Normal & $60.38 \pm 4.06$ & $50.67 \pm 3.43$ & $56.92 \pm 6.95$ & $69.25 \pm 6.83$ \\
\hline & Parallel & $52.75 \pm 6.53$ & $45.5 \pm 2.88$ & $47.17 \pm 3.62$ & $67.58 \pm 2.23$ \\
\hline \multirow{2}{*}{$\begin{array}{c}\text { Ball Burst } \\
\text { Distension (mm) }\end{array}$} & Crack & $8.26 \pm 0.42$ & $13.09 \pm 0.22$ & $13.77 \pm 0.96$ & $17.66 \pm 0.06$ \\
\hline & Burst & $9.19 \pm 0.67$ & $16.4 \pm 0.23$ & $16.38 \pm 0.48$ & $17.77 \pm 0.03$ \\
\hline \multirow[t]{2}{*}{ Flexing Endurance } & Normal & $\begin{array}{c}\text { No damage @ } \\
50,000 \text { flexes }\end{array}$ & $\begin{array}{c}\text { No damage @ } \\
50,000 \text { flexes }\end{array}$ & $\begin{array}{r}\text { No damage @ } \\
50,000 \text { flexes }\end{array}$ & $\begin{array}{r}\text { No damage @ } \\
50,000 \text { flexes }\end{array}$ \\
\hline & Parallel & $\begin{array}{c}\text { No damage @ } \\
50,000 \text { flexes }\end{array}$ & $\begin{array}{c}\text { No damage @ } \\
50,000 \text { flexes }\end{array}$ & $\begin{array}{r}\text { No damage @ } \\
50,000 \text { flexes }\end{array}$ & $\begin{array}{r}\text { No damage @ } \\
50,000 \text { flexes }\end{array}$ \\
\hline Shrinkage temperature $\left({ }^{\circ} \mathrm{C}{ }^{\circ} \mathrm{C}\right)$ & & 108 & 115 & 118 & 115 \\
\hline Uniformity coefficient $\left(\mathrm{K}_{\text {unif }}\right)$ & & 1.1446 & 1.1136 & 1.206699 & 1.024 \\
\hline
\end{tabular}

\section{Anisotropic Effect on Physical Properties of Leather}

Tensile strength values for samples cut in parallel to the backline were higher than for perpendicular samples. Structurally, for the samples cut along backline, majority of their fibres are already aligned in the same direction as the applied strain, hence they have little scope to orientate towards the strain axis [9]. This therefore means that the fibres themselves are directly strained at low levels of nominal strain and the process of fibre orientation is limited. For samples cut perpendicularly, many fibres are aligned normal to the direction of the applied strain, therefore, the fibres orientate towards the strain axis. This orientation minimizes levels of nominal strain and deformation occurs by straining themselves. Further deformation is associated with straining of the fibres themselves. Since tensile strength is proportional to the number of fibres aligned in that direction, its value is higher in the parallel orientation because the strain is being applied to a more orientated network of fibres than the case for perpendicular sampling. Fibre orientation will cause frictional damage to the fibres, and therefore increases the tensile strength. In perpendicular sampling, more fibre orientation thereby increasing the possibility of fibre damage and reducing tensile strength.

Tear strength and percentage elongation values for specimens sampled along the backline were less than the value for specimen sampled 
perpendicular to the backline. When specimens are oriented parallel to the backbone, the general fibre direction is assumed to be in the same direction as the strain axis. Under these conditions, the specific work of fracture is higher because the tear does not propagate through fibre diameters. Instead, the fibres bridge the advancing tear and are subject to more of a straightforward rupturing process. In addition, when specimens are oriented in a direction perpendicular to the backline, the general fibre direction is assumed to be nearer 900 to the strain axis. Therefore, the specific work of fracture is lower because the tear is able to propagate directly through the felt work of fibres and tear strength is higher. In addition to the above explanation, when the samples for tear analysis are taken in parallel, the direction of tearing is in perpendicular and vice versa [9]. This explains the higher tear strength and elongation for samples cut in perpendicular, a negative trend, compared to tensile strength.

\section{Effect of Retanning on the Physical Properties of Leather}

Retanned samples were observed to be structurally more compact and full and its grain surface was mechanically tighter compared to others. Retanning slightly increased tensile strength, tear strength, distension at crack and burst and shrinkage temperature. On the other hand, percentage elongation decreased after retanning. For all the tanned and retanned specimens tested for flexural endurance, there was no observable damage at 50,000 flexes. Results from this study show that leathers at both tanned and retanned stages of processing are appropriate for most of the leather applications. The margins of the results and patterns reported in this study are comparable to other related publications [28-32]. An increase in flexural endurance after retanning has also been observed by [33]. References [34, 35] reported an increase in tensile strength and shrinkage temperature after retanning process. Retanning using chromium salts imparts extra crosslinks into the crust. These alkali salts form hydrogen bonds with hydroxyl components from the carboxyl units present in the aspartic and glutamic acids from the collagen of the crust [36]. Kinetic theory predicts increase in strength as the degree of crosslinking increases [37-39]. This explains the increase in tensile strength, tear strength, shrinkage temperature, and distension properties. Extra crosslinks reduces fibrillar (molecular) mobility and increased rigidness of the leather matrix between fibrils and within fibre bundles which impose mechanical restraints. These additional crosslinks act as rigid particulate fillers to a leather polymer matrix which decreases the elongation at break. Similarly, tanning induces bonding between the basic fibres. Mechanically, the bonds formed inhibit the realignment and straightening process of the fibres which slightly weakens the extensibility of the retanned leather.

\section{Effect of Dyeing on Mechanical Properties of Leather}

The chemical nature and intrinsic polyfunctionality of dyes allows the formation of chemical bonds, van der Waals interactions and additional hydrogen bonds. Although these functionalities were expected to improve the physical properties, dyeing process was observed to decrease both tensile and tear strengths while it increased elongation, shrinkage temperature and distensions at grain crack and burst. The bonds or links formed are weaker [40]. Decrease in shrinkage temperature after dyeing has been reported by [30]. The authors attributed the decrease in tensile strength and tear strength to poor adhesion between the dye and leather matrix. In our present study, the claims can be 
refuted because the dye bath was slightly acidic, facilitating the swelling of the leather substrate especially in the presence of water. Similarly, the temperatures of the dyeing processes were slightly higher than room temperature hence there is an increased mobility of the molecule segments in the polymer [40]. The two factors work together to improve the dispersion and distribution of dye molecules in the leather substrate and suitable adhesion between the substrate and molecules. On the other hand, the very penetration of the dye particles into leather matrix decreases the energy of the intermolecular interaction and therefore destroys a significant portion of the already stable intermolecular bonds. Additionally, increased segmental mobility due to the said temperatures favours the disorientation of the collagen fibres. Modeling dyed crust as the heterogeneous composite, the mechanism of micromechanical deformations and macroscopic properties depend on local stress distribution around the fillers/inclusions. Poor adherence of the filler to the crust implies that the fillers are unable to carry any load, making it weak body. This is because stress concentrations will be created around the particles, reducing the composite strength. We also hypothesized the mechanism whereby the oily nature of dyes in collagen imparts water retention ability. The polar or amphoteric nature of dyes has also been associated with level of hydration which also increases collagen's D-spacing [41]. The increased D-spacing leaves more free volume for water attachment. The water retention alters the collagen's structure at the fibrillar scale. The water attached disrupts hydrogen bonds which provide structural integrity to the molecular backbone of collagen and therefore decreases the strength properties of leather.

\section{Effect of Fatliquoring on Organoleptic and Physical Properties of Leather}

Fatliquored samples were softer, loose in structure and more pliable compared to other samples. Our observations agree with results in [41]. Reference [42] observed that penetration of fatliquors into leather increases its looseness. It was also observed in this study that fatliquoring modifies mode of break; induced both fibre rupture and pull-out (fine break). Fatliquored samples tore instead of snapping abruptly. This is fine break, which is normally dominant where collagen distribution is uniform and there are many fine wrinkles per unit length, and it usually indicates good quality leather [43]. Although it has been argued by [24] that any tannery processes that prevent the fibrils from sticking together tightly on the grain surface definitely produces fine break, the tanned, retanned and dyed samples (fatliquor-free hide) were almost brittle and snapped at break. This type of break is a result of snapping of individual fibres themselves. This deformation behavior can be explained by using fibre recruitment model by [44]. In this model, we hypothesized that fatliquoring effectively lubricates the crust weave which opens up its structure allowing its collagen fibres to align along the direction of the applied stress at low strains before the fibres themselves get elongated at high strains. Since there are different degrees of tautness of the collagen fibres in the weave, only few fibres get taut at the beginning of the strain but as the strain increases, more fibres get taut and the strength increases [45]. During break, some of the fibres pull apart while some get taut before others and break. However, in the unfatliquored (tanned, retanned and dyed) crusts, where the higher degree of fibre adhesion makes the material to have closed compact and solid structure. In such a weave, the constituent fibres do not slide but extend on their own during elongation. This means that no fibre gets taut at 
low strains due to fibre adhesion. At break, some fibres get taut before others and rupture making the weave to snap. For this reason, fatliquoring can be recommended since this type of break is desirable for majority of today's customers.

Fatliquored samples recorded lower tensile strength and shrinkage temperature as compared to dyed samples. The same pattern was observed by [46] and [31]. The range of our results for fatliquored samples is comparable to other studies [47-49]. The tear strength, percentage extension and distensions at crack and burst of fatliquored crust were significantly greater than those for dyed crusts $(p=0.01267)$. This indicates that fatliquoring increases tear strength, elongation at break and distension of leather. This trend resonates with results reported by [46] and [31]. The results for elongation of fatliquored leather agree with those previously published by $[20,48,50]$. The increase in elongation was attributed to the sliding effect of the fat liquors in the fibres [46]. The trend for tensile strength and shrinkage temperature contradicted our hypothesis. It's expected that fatliquored crust permits the easy sliding of fibres against each other and aid in the stress distribution during the extension, a fact that ought to raise tensile strength and shrinkage temperature [51]. Be it as it may, the authors explained the decrease of tensile strength and shrinkage temperature and increase of tear strength, elasticity and distension, in three ways. The explanations modeled fatliquors in the collagen network as primary plasticizers, secondary plasticizers and humectants [41, 52-53]. As primary plasticizers, the synthetic sulphated oils used in this study are anionic colloids with large molecules carrying a negative charge. Usually, after chrome tanning, the wet blue crust are neutralized, making them slightly acidic and cationic in nature. This ensures that the anionic oil molecules penetrate into the gaps of collagen fibres, their polar groups being attracted to the crust fibres through the cross section; forming a lubricant film around the collagen fibres. This ionic interaction of the two polar groups neutralizes the attractive forces between crust matrixes, weakening the Van der Waals forces between adjacent polymer chains. Hence in aqueous environment, it's accurate to model fatliquors as primary plasticizers. As secondary plasticizers, the inert molecules of fatliquors disperse within the leather matrices like fillers, providing mechanical spacers that separate adjacent collagen chains hence reducing Van der Waals forces. This reduces the number of fibre adhesion in the weave [54]. Low or poor adhesion between the crust matrix and fatliquors can explain the decrease in tensile strength and shrinkage temperature while supporting the explanation for increase in extensibility and tear strength [54-55]. As humectants, findings from Synchrotron scattering experiments have shown that fatliquors enhance water-retention capacity in the collagen [41]. The high hydration level which is the reason for increased d-spacing of collagen also affects the physical properties. Therefore, the decrease in elasticity and increase in tensile strength are consequence of the increased d-spacing. In all the three explanations above, the leather structure weakens as a result of decreasing Van der Waals forces. The decrease consequently reduces the resistance of the crust to deformation [20]. Reference [56] termed the weakening as destabilizing the crust and reversing the crosslinking action of the chrome tanning. Reversing crosslinking action definitely reduces the tensile strength and shrinkage temperature $[6,9,12]$. This also explains why the fibre bundle allows the constituent fibres to straighten up and align themselves in the direction of the deforming force before the fibres actually get to be stretched and hence elongation at break, softness and pliability. Some differences can also be attributed to the difference in the sample locations although minimal since all samples were cut within the official sampling location where anisotropic variations are minimal. 


\section{Effect of Crusting Processes on Leather's} Anisotropy and Uniformity

It was anticipated in this study that some features of the collagen structure can purposefully change and transform its fibrous structure during the crust processing, and this influences the deformation properties of the resulting leather. The degree of anisotropy in the leather was estimated according to relaxation and deformation properties. The uniformity coefficient Kunif of the physical properties of leather was determined as the ratio of the average values of the elongations in transverse directions to the average values in the longitudinal direction. The changes in the coefficient were employed to infer dermal microstructural changes due to the underlying crust process. The coefficients of the crusted leathers were calculated using equation 1 .

$$
K_{\text {unif }}=\frac{\epsilon_{\text {normal }}}{\epsilon_{\text {parallel }}} K_{\text {unif }}=\frac{\epsilon_{\text {normal }}}{\epsilon_{\text {parallel }}}
$$

It found out that retanning decreases the coefficient by $2.7 \%$. This implies that retanning disrupts the hierarchy of collagen hence disrupting the uniformity. Dyeing increased the coefficient by $8.36 \%$ which means that dyeing stabilizes the structure of collagen. Fatliquoring decreased the coefficient by $15.14 \%$. This is the greatest decrease among the three processes considered. This implies that fatliquoring is the most destructive crusting process to the leather uniformity. This observation corroborates the results by Sizeland et al. [41] and Dutta [42]; penetration of fatliquors into leather increases looseness, softness and pliability.

\section{CONCLUSIONS}

All the samples tested showed enough strength properties according to the recommended minimum tear strength, tensile strength, percentage elongation, distension at crack and burst and flexing for garment leathers, linings, and shoe upper leathers. Apart from the minimal effect of sampling the specimens from the same cowhide and hence variation in location, retanning improves tear and tensile strengths, distensions at crack and burst, and shrinkage temperature. It also improves the organoleptic propertiessuch asfullness. However, the uniformity coefficient and percentage elongation decreased after retanning. Dyeing increased the elongation at break, distensions at crack and burst, shrinkage temperature and uniformity coefficient whereas both tensile and tear strengths decreased after dyeing. Similarly, fatliquoring increases elongation at break values, and distension values while decreases tensile and tear strengths, shrinkage temperature and uniformity coefficient. All the samples tested at all stages of processing indicated no damage at 50,000 flexes. Among the other beneficial effects of fatliquoring, induction of tearing type of break instead of the undesirable snapping makes it a necessary process, since this type of break is desirable for majority of today's customers.

\section{Acknowledgment}

The authors would like to acknowledge the National Research Fund-Kenya for the research fund. We also acknowledge Elsie Salano, Egerton University - Biochemistry Department, for helping in the sample procurement and preparation.

\section{Conflict of Interest}

The authors of this manuscript declare that no conflict of interest exists regarding its publication. 


\section{REFERENCES}

1. Mutlu, M.M., Ork, N., Yegin, O., Bas, S., Annals of University of Oradea, 2014, 51, 157-162.

2. Liu, C.K., Latona, N.P., Ashby, R., Ding, K., J Am Leather Chem As, 2006, 101, 368-75.

3. Joseph, K., Nithya, N., J Clean Prod, 2009, 17, 676-682, https://doi.org/10.1016/j. jclepro.2008.11.018.

4. Urbanija, V., Gersak, J., J Soc Leath Tech Ch, 2004, 88, 181-190.

5. Ork, N., Ozgunay, H., Mutlu, M.M., Ondogan, Z., Tekstil ve Konfeksiyon, 2014, 24, 413-418.

6. Nalyanya, K.M., Rop, R.K., Onyuka, A., Migunde, P.O., Ngumbu, R.G., J Therm Anal Calorim, 2016a, 123, 1, 363-370, https://doi. org/10.1007/s10973-015-4851-2.

7. Musa, A.E., Gasmelseed, G.A., International Journal of Advanced Industrial Engineering, 2013, 1, 1, 9-15.

8. Kowaiska, M., Zbikowska, A., J Soc Leath Tech Ch, 2014, 98, 23-29.

9. Nalyanya, K.M., Rop, R.K., Onyuka, A., Kamau, J., Int J Sci Res, 2015, 4, 3, 2149-2154.

10. Krishnamoorthy, G., Sadulla, S., Sehgal, P.K., Mandal, A.B., J Clean Prod, 2013, 42, 277-286, https://doi.org/10.1016/j. jclepro.2012.11.004.

11. Salehi, M., Lavvaf, A., Farahvash, T., Iran J Appl Anim Sci, 2013, 3, 4, 853-857.

12. Nalyanya, K.M., Rop, R.K., Onyuka, A., Migunde, P.O., Ngumbu, R.G., J Appl Polym Sci, 2016b, 133, 43208, https://doi.org/10.1002/ app.43208.

13. Zapletal, P., Szarek, J., Weglarz, A., Gardzina, E., J Soc Leath Tech Ch, 1996, 80, 118.
14. Valeika, V., Sirvaityte, J., Beleska, K., Materials Science (Medziagotyra), 2010, 16, 4, 330-336.

15. Ali, S.B., Haroun, H.E., Musa, A.E., Journal of Forest Products and Industries, 2013, 2, 5, 25-29.

16. Wells, H.C., Edmonds, R.L., Kirby, N., Hawley, A., Mudie, S.T., Haverkamp, R.G., J Agr Food Chem, 2013, 61, 47, 11524-11531, https:// doi.org/10.1021/jf4041854.

17. Bacardit, A., Burgh, S., Armengol, J., Olle, L., J Clean Prod, 2014, 65, 568-573, https://doi. org/10.1016/j.jclepro.2013.09.052.

18. Negussie, F., Urge, M., Mekasha, Y., Animut, G., Sci Technol Arts Res J, 2015, 4, 2, 222-227.

19. Cuq, M.H., Benjelloun-Mlayah, B., Delmas, M., J Am Oil Chem Soc, 1998, 75, 8, 10151019, https://doi.org/10.1007/s11746-9980280-8.

20. Liu, C.K., Latona, N., Dimaio, G.L., J Am Leather Chem As, 2002, 97, 431-440.

21. Zarlok, J., Smiechowski, K., Mucha, K., Tęcza, A., J Clean Prod, 2014, 65, 583-589, https:// doi.org/10.1016/j.jclepro.2013.07.044.

22. Jankauskaite, V., Jiyembetova, I., Gulbiniene, A., Sirvaityte, J., Beleska, K., Urbelis, V., Materials Science (Medžiagotyra), 2012, 18, 2, 150-158.

23. Nielsen, L.E., Landel, R.F., Mechanical properties of polymers and composites, CRC Press, Taylor \& Francis Group, Boca Raton, 1994.

24. Liu, C.K., Latona, N.P., Taylor, M., Eble, C., Aldema-Ramos, M.L., J Am Leather Chem As, 2015, 110, 88-93.

25. UNIDO, Acceptable Quality standards in the Leather and Footwear Industry, United Nations Industrial Development Organization, Vienna, 1996. 
26. Roig, M., Segarra, V., Bertazzo, M., Martínez, M.A., Ferrer, J., Raspi, C., Journal of AQEIC, 2012, 63, 4, 101-111.

27. Heidemann, E., Fundamentals of Leather Manufacturing, Eduard Roether KG, Darmstadt, London, 1993.

28. Inanc, L., Gulumser, G., Tekstil ve Konfeksiyon, 2015, 25, 4, 365-370.

29. Ashebre, A.M., International Journal of Advancements in Research \& Technology, 2014, 3, 3, 26- 30.

30. Jian, Z., Shuxiang, H., Yanan, W., Qiang, H., Xueping, L., Wenhua, Z., Bi, S., J Soc Leath Tech Ch, 2012, 95, 1-7.

31. Hassan, E.A., Ibrahim, M.T., Sally, K.A., J Agric Vet Sci, 2014, 15, 1, 87-94.

32. Seggiani, M., Puccini, M., Vitolo, S., Chiappe, C., Pomelli, C.S., Castiello, D., Clean Technol Environ Policy, 2014, 16, 1795-1803, https:// doi.org/10.1007/s10098-014-0722-y.

33. Gumel, S.M., Dambatta, B.B., Int J Chem Eng Appl, 2013, 4, 4-8.

34. Nashy, E.H.A., Hussein, A., Essa, M.M., J Am Leather Chem As, 2011, 106, 9, 241- 248.

35. Zengin, A.C.A., Crudu, M., Maier, S.S., Deselnicu, V., Albu, L., Gulumser, G., Bitlisli, B.O., Basaran, B., Mutlu, M.M., Ekoloji, 2012, 21, 82, 17-25, https://doi.org/10.5053/ ekoloji.2011.823.

36. Liao, L.L., Chen, W.Y., Shan, Z.H., Dan, W.H., Tanning chemistry and technology, Beijing: Science Press, 2005.

37. Flory, P.J., Principles of Polymer Chemistry, Cornell University Press, Ithaca, N.Y., Chapter 11, 1953.
38. Treloar, L.R.G., The Physics of Rubber Elasticity, Clarendon Press, Oxford, 1956.

39. Tyagi, P.K., International Journal of Engineering Technology, Management and Applied Sciences, 2017, 5, 7, 216-221.

40. Nedkova, M., Pavlov, P., Pishev, D., Autex Res J, 2005, 5, 162-175.

41. Sizeland, K.H., Wells, H.C., Kelly, S.J.R., Edmonds, R.L., Kirby, N.M., Hawley, A., Mudie, S.T., Ryan, T.M., Haverkamp, R.G., RSC Adv, 2017, 7, 40658.

42. Dutta, S.S., An introduction to the principles of leather manufacturing, 4th Ed Indian Leather Technologists Association, 2008, 506557.

43. Diebschlag, W., Leder, 1975, 26, 7-18.

44. Kronick, P.L., Beuchler, P.R., J Am Leather Chem As, 1986, 81, 221.

45. Attenburrow, G.E., J Soc Leath Tech Ch, 1993, 77, 107.

46. Gutters, M., Santos, L.M.D., J Soc Leath Tech Ch, 2009, 93, 171-175.

47. Sivakumar, V., Prakash, P.R., Rao, P.G., Ramabrahmam, B.V., Swaminathan, G., J Clean Prod, 2008, 16, 549-553, https://doi. org/10.1016/j.jclepro.2007.01.006.

48. Quadery, A.H., Uddin, M.T., Azad, M.A.K., Chowdhury, M.J., Deb, A., Hassan, M.N., IOSR Journal of Applied Chemistry, 2015, 8, 1, 5458.

49. Valeika V., Širvaitytè J., Beleška K., Valeikienè V., Essential Oils as Antioxidants for Fatliquoring Emulsion, ICAMS 2012 4th International Conference on Advanced Materials and Systems, 315-320, 2012. 
50. Zengin, A.C.A., Colak, S.M., Zengin, G., Kilic, E., Arch Environ Prot, 2014, 40 1, 3-12, https://doi.org/10.2478/aep-2014-0003.

51. Covington, D., Alexander, K.T.W., J Am Leather Chem As, 1993, 88, 241-53.

52. Jun, M., Zonghui, L., Deqing, W., China Leather, 1998, 27, 11, 1-3.

53. Zhengjun, L., Wuhou, F., Qinhuan, Y., Ye, T., J Soc Leath Tech Ch, 2015, 98, 167-171.

54. Hu, Y., Jang, I., Sinnott, S.B., Compos Sci Technol, 2003, 63, 1663-1669, https://doi. org/10.1016/S0266-3538(03)00055-1.
55. Ervina, J., Mariatti M., Hamdan, S., Procedia Chem, 2016, 19, 897-905, https://doi. org/10.1016/j.proche.2016.03.132.

56. Kronick, P.L., J Am Leather Chem As, 1996, 91, 246-251.

(C) 2018 by the author(s). Published by INCDTPICPI, Bucharest, RO. This is an open access article distributed under the terms and conditions of the Creative Commons Attribution license (http:// creativecommons.org/licenses/by/4.0/). 